\title{
IAMJ
}

INTERNATIONAL

AYURVEDIC

MEDICAL JOURNAL

\section{COMPARATIVE ANALYSIS OF JWARA CHIKITSA SIDDHANTA AMONG THE CHARAKA SAMHITA AND SUSHRUTA SAMHITA}

\author{
Avula Srinivas \\ MD (Ayu samhita), Associate Professor, Dept of Samhita Siddhantha, Raja Rajeshwari Ayurvedic Medical \\ College and Hospital, Humnabad, Bidar District, Karnataka. India
}

Corresponding Author: srinivasonu16@gmail.com

https://doi.org/10.46607/iamj2809102021

(Published Online: October 2021)

Open Access

(C) International Ayurvedic Medical Journal, India 2021

Article Received: 26/09//2021 - Peer Reviewed: 06/10/2021 - Accepted for Publication: 07/10/2021

Check for updates

\begin{abstract}
Jwara is one of the dreadful diseases, which affects the human body, mind as well as senses. The Jwara has been described in Charaka Samhita and Sushruta samhita in detail. Charaka Samhita is considered as medicine oriented where it is mentioned that due to Nidana the aggravated Dosas afflicts the Amasaya, mixes up with Agni and causes Sroto avarodha of Rasa and Sweda and further suppresses the Agni and expels heat from the site of digestion and spreads all over the body results in the Jwara. Whereas Sushruta Samhita is having the influence of surgical interventions mentions that a man comes to this world with Jwara and departs with it. Jwara was originated from the wrath of Lord Rudra, it is considered the king of all diseases and destroyer of all creatures. Jwara is also found in other literature like mahabharatas and Puranas etc, as Jwara destroys the body as well as Dhatus, it is called Kshaya, as Jwara produces Moha it is also called as Tama and as it kills the person like Yamaraja it is called as Yamatmaka. So here an attempt has been made to understand the Jwara chikitsa siddhanta (principles) among the Charaka samhita and Sushruta samhita with their similarities and specifications.
\end{abstract}

Keywords: Jwara, Charaka samhita, Sushruta samhita, Fever. 


\section{INTRODUCTION}

Samhitas are the source of knowledge of Ayurveda. To achieve the four pursuits of life, Ayurveda helps to maintain health and cure the disease. Diseases are described in Samhitas with their aetiology, sign symptoms and management. Jwara (fever) is a disease that is present at the time of birth and death also. Jwara is considered an important disease as it afflicts the body, mind and senses. In Charaka samhita jwara has been described with its aetiology, sign symptoms and management principle in Nidanasthana, whereas its detailed management with different types described in chikitsasthana. In Sushruta Samhita, the jwara has been described with its aetiology, sign symptoms and management principle in chikitsasthana. ${ }^{1,2}$ In Sushruta samhita jwara chapter initiated as the one among the sixteen complications of vrana. But furthermore, in the same chapter in a detailed description of jwara with its types, sign symptoms, management has been described. ${ }^{3}$ So here the similarities and specifications of the jwara chikitsa siddhanta(principles) among the Charaka samhita and Sushruta samhita have been reviewed and discussed.

Aim: Comparative study of Jwara chikitsa siddhanta among the Charaka samhita and Sushruta samhita.

Objectives: To study the Jwara chikitsa siddhanta from Charaka Samhita, to study the Jwara chikitsa siddhanta from Sushruta Samhita

Material and Methods: Charaka Samhita, Sushruta samhita

\section{Observations:}

Mythological origin: Charaka samhita and Sushruta samhita both consider the origin of jwara is from lord Shiva. Jwara is considered supreme among all the diseases named by a different name in a different creature. ${ }^{4,5}$ Due to presence of devotional power in human being they can tolerate the fever, but rest of all animals could not survive once get afflicted by fever. $^{5}$

\section{Types:}

\section{Classification of jwara; -}

Charaka Samhita ${ }^{6}$; -

Nija jwara- twofold, threefold, fourfold, sevenfold
A] Twofold: sharirika manasika, Soumya aagneya, Antarvega bahirvega, Prakruta vaikruta, Sadhya asadhya

B] Fivefold: santat, satat, anyedushka, tritiyaka, chaturthaka

C]Sevenfold: saptadhatugata

D] Eightfold: As per the cause

E] Sannipataj jwara described in detail with its thirteen types

Sushruta samhita ; -

A] There are eight types of jwara

B] The types of sannipataja jwara has been described as abhinyasa, hatoujas, sanyasa, ojonirodhaja.

C] Vishamajwara Satat, anyedushka, trutiyaka, chaturthaka, pralepaka

D] Dhatugata jwara.

In Charaka samhita following points have been highlighted: ${ }^{8}$

Jwara prakruti: Sharirika: vata, pitta, kapha and Manasika: Raja, Tama. Jwara prabhava: santapa, aruchi, trushna, angamarda, hradi vyatha, present at the time of birth and death. Adhishthana: whole body with the mind. Pratyatma laxana: santapo deha manasa. Mana santap laxan: vaichitya, arati, glani. Indriya santap: Indriya vaikruti.

Nidana:

Charaka samhita: ${ }^{9}$ In nidanasthana there is a description of eight types of jwara. The Strotas involved in the occurrence of jwara is Rasavaha and Swedavaha. Nidana, samprapti and laxanas have been described separately for vataj, pittaja, kaphaja, Dwandaja, sannipataja jwara. Vishamprajanana and prajata mithyopachara are also elaborated as a cause for jwara. In Sushruta samhita the common causative factor for jwara has been described viz., Snehadi karma mithyayoga, atiyoga, Abhighat, Rogotthana prapakata, shrama, kshaya, ajeerna, visha, satmya viparyaya, rutu viparyaya, oushadhi pushpa gandha, shoka, nakshatrapeeda, abhichar, abhishap, manasika abhishang, Apprajata, ahita sevan prajata, stanyaavataran. ${ }^{7}$ 


\section{Purvarupa:}

In Charaka samhita the prodromal signs of fever have been described as, aalasya, nayanasrava, jrumbha, gourava, klama, bhakta dwesha, avipaka, aasyavairasya, balahani, varnahani, alpa sheela vaikruta. ${ }^{10}$

The general prodromal sign and symptoms have been described in Sushruta samhita, along with the specific prodromal sign and symptoms in concern with involved doshas are described. Vata- jrumbha (yawning) Pitta- nayan dah (burning sensation in eyes), Kapha- na anna abhinandan (no desire for food)

The sign and symptoms of vataj pittaja and kaphaja jwara have been described in detail. Dwandwaja jwaras description has been also described. ${ }^{11}$

Jwara samanya laxana: swedavrodha, santap, sarvangagrahan.

Jwara samprapti:

Charaka samhita describes the samprapti of jwara with its nidana in detail with individual types in $n i$ danasthana. Furthermore, in chikitsasthana the common samprapti have been described. In Sushruta samhita common samprapti have been described. The vitiated doshas when pulls out the aamaashaya ushma into rasavaha and swedavaha strotas. The obstruction occurs in a strotas, agni gets diminished and manifest the jwara.

Sign and symptoms of curable, not curable fever: ${ }^{12}$

In Charaka samhita following signs and symptoms have been described for curable, not curable fever. Curable: afflicted to strong person, involvement of alpa dosha, having no complications. Not curable: the presence of multiple causes and having multiple signs and symptoms.

wara with severe pralapa, bhrama, shwasa takes away the life of a person as seven days in vataj jwara, 10 days in pittaja jwara, and 12 days in kaphaja jwara.

Jwara is afflicted to weak person, having edema, kesha seemant krut is not curable.

\section{Samanya jwara chikitsa}

The principles of jwara chikitsa have been described in both samhitas.

Table 1

\begin{tabular}{|l|l|l|}
\hline Stage & Charaka Samhita & Sushruta samhita \\
\hline Purvarupa & Laghu, apatarpana & $\begin{array}{l}\text { Vataj- Pure ghee } \\
\text { Pittaj-Virechana } \\
\text { Kaphaja-Mrudu Prachachardhana }\end{array}$ \\
\hline Aamashaya samuttha: $:$ & $\begin{array}{l}\text { kashayapana, abhyanga, sneha, sweda, } \\
\text { pradeha, parisheka, } \\
\text { lepana, vaman, virechana, aasthapana, anuvasan, } \\
\text { nasya, dhupa, dhuma, ksheerabhojana. }\end{array}$ & $\begin{array}{l}\text { Apatarpan } \\
\text { Vaman } \\
\text { Langhana } \\
\text { Ushnambu } \\
\text { Vaman, Viechana, Aasthapana, shirovirechana }\end{array}$ \\
\hline Jeerna jwara: & Sarpi pana. & Sarpi pan \\
\hline
\end{tabular}

The treatment principles of jwara in Charaka samhita have been described as follows, ${ }^{15,16,17}$

The sign and symptoms of Aamajwara, Pachyamana jwara, Nirama jwara have been described. Nava jwa$r a$ prohibited the Importance of langhana.

Siddha jala (Medicated drinks) to be administered in jwara:

Ushna jala in vata kapha jwara, Tiktaka shruta sheeta jala in madyaja and paittika jwara, Shadanga paniya in all kinds of fever.
Yavagu (gruel): The gruel must be administered till the fever diminishes or till six days. The yavagu is contraindicated in madatyaya, madyanitya, pitta kaphadhikya, urdhwag raktapitta. The administration of Tarpan, Peya, Yusha, Shaka, Mamsarasa, Jwaranashaka kashaya, Vishama jwaranashaka panchakashaya have been described. Administration of ghee- the jwara which is not subsided by decoction, vaman, langhana administer the ghrita. Ghritapana is advised in manda kapha, vata pittottar jwara. 
Ksheera is advised in daha trushna, vatapittottara jwara. Vamana (emesis) must be administered in a condition of nausea. Administration of kashaya after six days. Niruha basti - jwara ksheene. Virechanapitta, kaphapitta, pittashayagata. Bastipakwashayagata. Anuvasana- kapha pitta, dridhagni, ruksha baddha purisha. Nasya- gourav, shirashula, vibaddha indriya, jeerna jwara.

External Therapy- abhyanga, pradeha, parisheka, avagah, dhoop anjana. Sanshodhana- vamana and virechana must be adopted in bahudoshavastha as per the requirement. Milk: the milk must be administered in jeerna jwara processed with medicines as per need. Daha jwara- administers the sahasradhouta sarpi, chandanadi taila. Langhana is not advisable in vataj, shramaj, purana, kshataj jwara. Nirama jwara duration: the fever becomes nirama on the eighth day. Vataj jwara- Basti Pittaja jwara- Virechana Kaphaja jwara-Vaman, the treatment principles of Sushruata samhita have been described as follows ${ }^{14}$

\section{When Sign And Symptoms Occur:}

The Apatarpan is the first line of treatment. If doshas are present in Aamashaya then do vaman. The duration of fasting is till doshas are stagnant (stimit). Langhana is not indicated in vataj, kshayaja and manas jwara. Ushnambu is indicated in all kinds of jwara. Shadangasiddha peya has been described in Sushruta samhita. The decoction of medicine must be administering after seven nights. In Sushruta samhita Sama jwara and niramajwara sign symptoms have been described. Madya prayoga and ksheera prayoga are also described. The fever occurs in ap prajata and stanyavataran should be treated palliative. If a person is suffering from thirst in fever, then administer vaman with madhu and sheeta jala. Vaman, Viechana, Aasthapana, shirovirechana described in jwara. Administer the Ghee for mitigating the dryness of the body. Lajatarpana with sita and madhu should administer for thirst accompanied by burning sensation and vomiting.

Vishamajwara: ${ }^{18,}{ }^{19}$ In Sushruta samhita vishama jwara has been described in detail. When a person indulges in an unwholesome diet after treatment of jwara then vishamjwara occurs. The aagntuka (exog- enous) cause is also responsible for vishamajwara. Bhutabhishanga is also a cause for vishamajwara. In vishamajwara the dosha when reaches aamashya causes fever.

\section{Types:}

Charaka samhita ${ }^{20:}$ - Santata, Satata, Anyedushka, Tritiyaka, Chaturthaka are the types of vishamajwara.

Sushruta samhita ${ }^{21}$ : - Satat, anyedushka, trutiyaka, chaturthaka, pralepaka are the types of vishamajwara.

Santataka has been described in the duration of fever is also one of the types of satatak jwara.

Dhatugata jwara: ${ }^{22,23}$ In Charaka samhita Dhatugata jwara sign and symptoms have been described in detail as rasa, rakta, mamsa, meda, asthi, majja, shukra. Among them, Curable is rasa, rakta, mamsa, meda, Difficult to curable asthi, majja, and noncurable shukra. The sign and symptoms of dwandwaja jwara have been described In Sushruta samhita Sign and symptoms of jwara as per the residence in dhatus have been described. As per the involvement of doshas in dhatus(tissues) ekdoshaja, dwandwaj and sannipatik signs and symptoms have been described.

Saptadhatugata jwara treatment: Specific treatments for dhatugata jwara have been described in Charaka samhita.

Rasa -vaman, upawasa, Rakta- seka pradeha, palliative treatment, Mamsa, Meda-Virechana, upawasa, Asthi, Majja- Niruha, Anuvasan.

Sannipataj jwara: ${ }^{24,25}$ Sannipata jwara have been described in both samhitas. In Charaka samhita Sannipataj jwara is described with its thirteen types. In Sushruta samhita the types of sannipataja jwara has been described as abhinyasa, hatoujas, sanyasa, ojonirodhaja. In Charaka samhita stated that the sannipataja jwara present with all the signs and symptoms, digestive fire has been abolished, doshas are vibaddha (stagnant) then it is incurable otherwise difficult to cure In Sushruta samhita the duration for relief from sannipataj jwara is seven days, ten days or twelve days. 


\section{Sannipata Jwara Chikitsa:}

Increment of depleted doshas and minimizing the increased doshas with consideration of kapha is the principle in sannipata jwara chikitsa described in Charaka Samhita.

In Charaka samhita following treatment has been adopted in certain conditions.

\section{Raktamokshana:}

When inflammation occurs at the ear root at the end of sannipataj jwara then do the raktamokshan, sarpi- pan, predeha and navan. The fever which is not subsiding by the contrast treatment of sheeta ushna, ruksha, snigdha then raktamokshan will be the line of treatment. The fever occurs due to visarpa, $a b$ highata, visphotaka, the sarpi pana is the prime line of treatment.

\section{Aagantuja Jwara:}

Aagntuja jwara have been described in both the samhitas.

Table 2

\begin{tabular}{|c|c|c|}
\hline & Charaka samhita ${ }^{26}$ & Sushruta samhita ${ }^{27}$ \\
\hline Types & $\begin{array}{l}\text { abhighataj, } \\
\text { abhishangaj, } \\
\text { abhichaaraj, } \\
\text { abhishapaj }\end{array}$ & $\begin{array}{l}\text { Abhighataj, } \\
\text { vishajanya, } \\
\text { kama jwara, } \\
\text { abhicharaj, } \\
\text { abhishapaj, } \\
\text { abhishangaj }\end{array}$ \\
\hline $\begin{array}{lr}\text { Involvement } & \text { of } \\
\text { Dosha, } & \text { sign } \\
\text { symptoms } & \end{array}$ & $\begin{array}{l}\text { In Nidana sthana described as } \\
\text { Abhighataj-vata and dushta shonit } \\
\text { Abhishangaj-vata pitta } \\
\text { Abhichaaraj-sannipataj } \\
\text { Abhishapaj-sannipataj } \\
\text { In chikitsa sthana described as } \\
\text { Abhighata-vayu and rakta } \\
\text { Abhishanga- tridoshaprakopaka } \\
\text { Sign and symptoms are eightfold as } \\
\text { explained in unmada chapter } \\
\text { Abhishangaja jwara occurs due to } \\
\text { poisonous contamination can be treat- } \\
\text { ed with antipoisonous treatment } \\
\text { Kama jwara: dhyana nishwasa bahul } \\
\text { Bhaya jwara- shoka, bashpa bahula }\end{array}$ & $\begin{array}{l}\text { Oushigandhaja jwara: unconsciousness, headache, vomiting, } \\
\text { sneezing. } \\
\text { Kamaj jwara: altered consciousness, stupor, laziness, anorex- } \\
\text { ia, pain at heart region. } \\
\text { Abhishangaja jwara- bhutavidya, bandhana, poojan } \\
\text { Blackish discolouration on the face, burning sensation, diar- } \\
\text { rhoea, catching pain at heart region, pain on an empty stom- } \\
\text { ach, thirst, pricking pain, unconsciousness, weakness are the } \\
\text { signs of a fever of poisonous origin. }\end{array}$ \\
\hline $\begin{array}{l}\text { Treatment princi- } \\
\text { ple }\end{array}$ & $\begin{array}{l}\text { Abhighataj Jwara- ghritapan, ab- } \\
\text { hyanga, raktamokshana } \\
\text { Kshataja Jwara- Kshata chikitsa } \\
\text { Vranaja Jwara- Vrana chikitsa } \\
\text { Kama, shoka, bhaya Jwara- Assur- } \\
\text { ance pleasure } \\
\text { Kamaja Jwara- manodnya, pittaghna } \\
\text { Krodha Jwara- polite statement. }\end{array}$ & $\begin{array}{l}\text { Manasa jwara- vidnyanadi } \\
\text { Shramaja, kshayaja ghrita, mamsarasa } \\
\text { Abhishapa, abhichara- homa } \\
\text { Utpata grahapidita: dana swastivachana, atithipujana } \\
\text { Abhighatajwara: ushna vivarjita kashaya, madhura, snigdha } \\
\text { yatha dosham }\end{array}$ \\
\hline
\end{tabular}




\section{Jeerna jwara: ${ }^{28,29}$}

Both samhitas have described the jeerna jwara. Sarpipana have been described as treatment in Charaka samhita In Sushruta samhita specific ghrita viz., Kalyanak ghrita, Mahakalyanak ghrita have been described.

Punaravartak jwara (Relapsing fever) ${ }^{30}$ : This is explained in Charaka samhita with its cause and treatment. Treatment adopted in punaravarataka jwara is mrudu shodhana, yapan basti, laghu yush, jangal mamsa, Abhyanga, Udwartana, snana, dhupan, anjana, tikta ghrita. In Sushruta samhita Gambhira jwara sign and symptoms viz., antardaha, trushna, aanaha, shwasa, kasa, and Asaadhya laxana viz., hataprabhendriya, ksheena, arochaka, tikshna vega have been described. ${ }^{31}$

\section{Jwaramukta Laxanas:}

In Charaka samhita sign symptoms in the process of relieving fever and sign symptoms of relieving fever have been described. Dos and Don'ts for the person who had got cured of fever were also explained. In Sushruta samhita signs symptoms of relief from fever have been described..$^{30}$ Shiro laghutwa, sweda, mukha apandu, mukha paka, kshavathu, annakanksha are the symptoms of a person who got relief from fever. ${ }^{32}$

\section{DISCUSSION}

The jwara has given foremost importance among both Samhita. The classification of jwara is described in both, but Charaka samhita have detail classification than that of Sushruta samhita. Sushruta samhita explained some types of jwara which are not found in Charaka samhita such as sannipataja jwara has been described as abhinyasa, hatoujas, sanyasa, ojonirodhaja. In Charaka samhita nidana has been described separately for each type of fever. In Sushruta samhita the common cause for nija jwara has been described. Stanyavaran as a cause for jwara have been described in Sushruta samhita. Both the treatise considers the rasawaha and swedavaha strotas involvement in the occurrence of fever. The description of specific prodromal signs as per the involvement of doshas is the contribution of Sushruta samhita. The treatment principle as per prodromal signs, aamavastha has been described in both samhitas. In Sushruta samhita administration of specific medicine as per the dosha involvement in the prodromal stage have been described viz., vataj- pure ghee, pittajvirechana, kaphaja - mrudu prachachardhana. The aagntuka (exogenous) cause and Bhutabhishanga other than vishamashan have been considered as a cause for vishamajwara in Sushruta samhita. Panchakashaya (five decoctions) have been exclusively explained in Charaka samhita for vishamajwara as per types. In both samhitas daivvyapashraya (worship of gods, auspicious things) and medicinal line of treatment has been described for vishamajwara. Sannipataj jwara has been described in both samhitas. Sushruta samhita stated the duration to relieve the fever in sannipataj jwara, whereas in Charaka samhita incurable signs have been described. In the treatment, aspect raktamokshana have been described in Charaka samhita but in Sushruta samhita in jwara chapter, there is no description of raktmokshana in jwara chikitsa. Both have described the jeerna jwara, sarpipana have been described as treatment in Charaka samhita. In Sushruta samhita specific ghrita viz., Kalyanak ghrita, Mahakalyanak ghrita have been described.

Punaravartak jwara (Relapsing fever) is explained in Charaka samhita with its cause and treatment. Even though the Sushruta samhita has an influence on surgical procedures the raktamokshana has been not described in jwara chikitsa but Charaka samhita describes the utility of raktamokshana in jwara chikitsa. Panchakarma treatment: 
In both the samhitas panchakarma treatment has been adopted in jwara as per the condition of doshas and significant symptoms.

Table 3

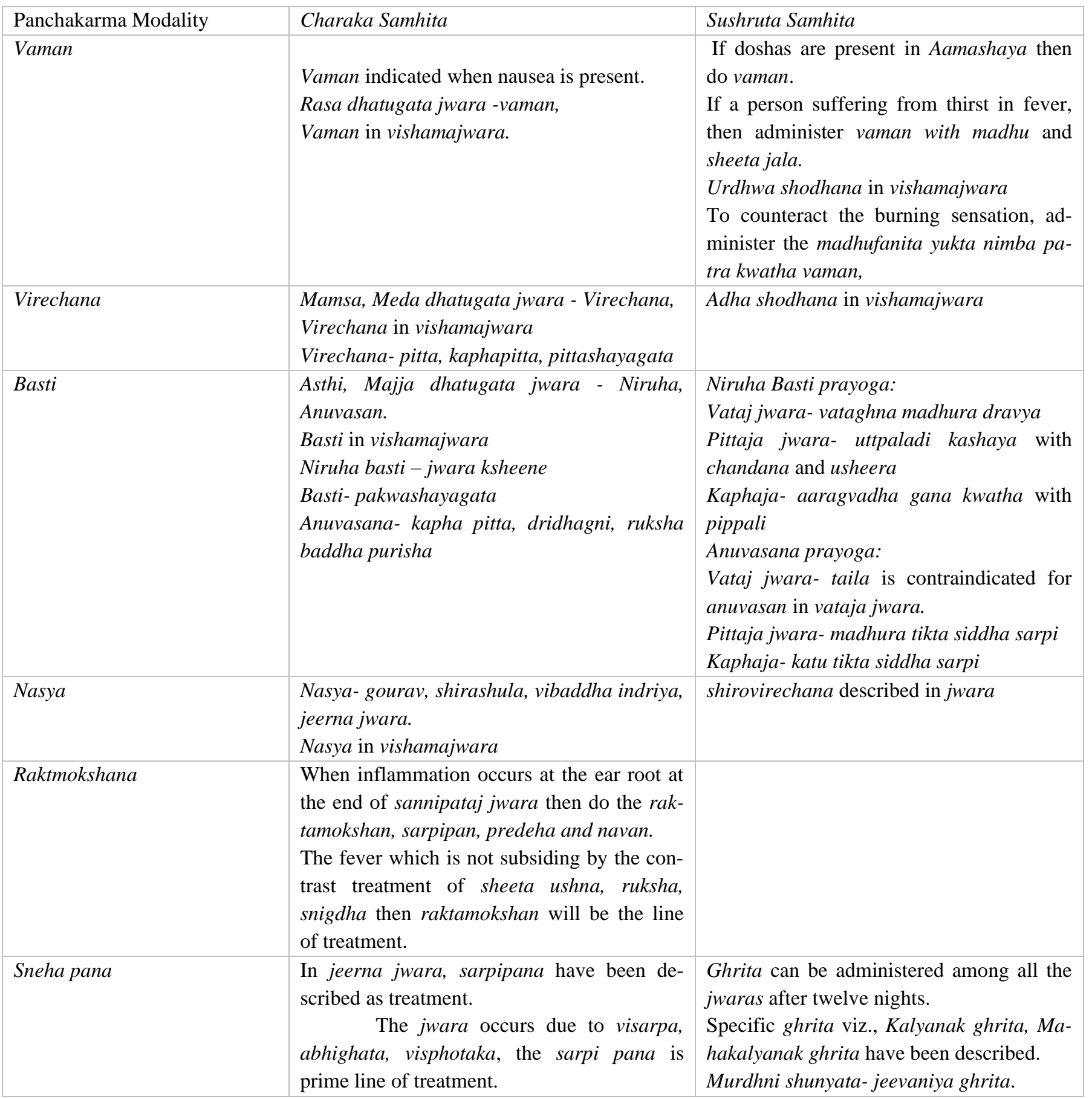

\section{CONCLUSION}

The basic classification of jwara is similar among both the samhitas. Apart from this Charaka samhita gives in detail the classification of jwara. Both the classics have a description about the aama, rasavaha strotas, swedavaha strotas. The nidana (causative factor) have been described in Charaka samhita for each type of fever separately. The specific purvarupa 
as per doshic predominance and treatment accordingly is a contribution from Sushruta samhita. Stanya pravanata (lactation) has been considered as one of the causes of the occurrence of jwara in Sushruta Samhita. Jwara has been described as an endogenous disease in Charaka samhita whereas in Sushruta samhita jwara has been considered primarily as a complication of wound (vranopdrava), but later in chapter highlighted its endogenous nature. Dhatugata jwara have been described in both samhitas, but Charaka samhita described in detail about curable and not curable as per dhatugata stages. Charaka samhita describes the specific treatment as per dhatugata avastha. Both samhitas underlies the affliction of an exogenous factor in the occurrence of vishama jwara. Both the samhitas apply the jwara chikitsa siddhanta as per the stages and movement of doshas. In Sushruta samhita the raktamokshana has been not described in jwara chikitsa but Charaka samhita describes the utility of raktamokshana in jwara. Punaravartak jwara (Relapsing fever) is explained in Charaka samhita with its cause and treatment.

\section{REFERENCES}

1 Acharya J.T. Charaka samhita by Agnivesha revised by charaka and Dridhabala with the Ayurved Dipika commentary of Chakrapanidatta, Varanasi, Chaukhambha Sanskrit Sansthan, fifth edition, 2001, pn. 193,

2 Acharya J.T. Charaka samhita by Agnivesha revised by charaka and Dridhabala with the Ayurved Dipika commentary of Chakrapanidatta, Varanasi, Chaukhambha Sanskrit Sansthan, fifth edition, 2001, pn.398,

3 Acharya J.T. and Acharya N.R. Sushrutasamhita of Sushruta with nibandhasangraha commentary of sri Dalhanacharya, Varanasi, Chaukhambha orientalia, fifth edition 1992, pn.670

4 Acharya J.T. Charaka samhita by Agnivesha revised by charaka and Dridhabala with the Ayurved Dipika commentary of Chakrapanidatta, Varanasi, Chaukhambha Sanskrit Sansthan, fifth edition, 2001, pn.399,

5 Acharya J.T. and Acharya N.R. Sushrutasamhita of Sushruta with nibandhasangraha commentary of Sri
Dalhanacharya, Varanasi, Chaukhambha orientalia, fifth edition 1992, pn.671

6 Acharya J.T. Charaka samhita by Agnivesha revised by charaka and Dridhabala with the Ayurved Dipika commentary of Chakrapanidatta, Varanasi, Chaukhambha Sanskrit Sansthan, fifth edition, 2001, pn.400,406.

7 Acharya J.T. and Acharya N.R. Sushrutasamhita of Sushruta with nibandhasangraha commentary of Sri Dalhanacharya, Varanasi, Chaukhambha orientalia, fifth edition 1992, pn.672,673.

8 Acharya J.T. Charaka samhita by Agnivesha revised by charaka and Dridhabala with the Ayurved Dipika commentary of Chakrapanidatta, Varanasi, Chaukhambha Sanskrit Sansthan, fifth edition, 2001, pn.399, 400 .

9 Acharya J.T. Charaka samhita by Agnivesha revised by charaka and Dridhabala with the Ayurved Dipika commentary of Chakrapanidatta, Varanasi, Chaukhambha Sanskrit Sansthan, fifth edition, 2001, pn.199-201.

10 Acharya J.T. Charaka samhita by Agnivesha revised by charaka and Dridhabala with the Ayurved Dipika commentary of Chakrapanidatta, Varanasi, Chaukhambha Sanskrit Sansthan, fifth edition, 2001, pn. 400 .

11 Acharya J.T. and Acharya N.R. Sushruta Samhita of Sushruta with nibandhasangraha commentary of Sri Dalhanacharya, Varanasi, Chaukhambha orientalia, fifth edition 1992, pn.673.

12 Acharya J.T. Charaka samhita by Agnivesha revised by charaka and Dridhabala with the Ayurved Dipika commentary of Chakrapanidatta, Varanasi, Chaukhambha Sanskrit Sansthan, fifth edition, 2001, pn.403.

13 Acharya J.T. Charaka samhita by Agnivesha revised by charaka and Dridhabala with the Ayurved Dipika commentary of Chakrapanidatta, Varanasi, Chaukhambha Sanskrit Sansthan, fifth edition, 2001, pn.203.

14 Acharya J.T. and Acharya N.R. Sushruta Samhita of Sushruta with nibandhasangraha commentary of Sri Dalhanacharya, Varanasi, Chaukhambha orientalia, fifth edition 1992, pn.679-681.

15 Acharya J.T. Charaka samhita by Agnivesha revised by charaka and Dridhabala with the Ayurved Dipika commentary of Chakrapanidatta, Varanasi, Chaukhambha Sanskrit Sansthan, fifth edition, 2001, pn.408,409. 
16 Acharya J.T. Charaka samhita by Agnivesha revised by charaka and Dridhabala with the Ayurved Dipika commentary of Chakrapanidatta, Varanasi, Chaukhambha Sanskrit Sansthan, fifth edition, 2001, pn. 410,411

17 Acharya J.T. Charaka samhita by Agnivesha revised by charaka and Dridhabala with the Ayurved Dipika commentary of Chakrapanidatta, Varanasi, Chaukhambha Sanskrit Sansthan, fifth edition, 2001, pn.414,415.

18 . Acharya J.T. and Acharya N.R. Sushrutasamhita of Sushruta with nibandhasangraha commentary of Sri Dalhanacharya, Varanasi, Chaukhambha orientalia, fifth edition 1992, pn.675, 676

19 Acharya J.T. Charaka samhita by Agnivesha revised by charaka and Dridhabala with the Ayurved Dipika commentary of Chakrapanidatta, Varanasi, Chaukhambha Sanskrit Sansthan, fifth edition, 2001, pn.403, 404.

20 Acharya J.T. Charaka samhita by Agnivesha revised by charaka and Dridhabala with the Ayurved Dipika commentary of Chakrapanidatta, Varanasi, Chaukhambha Sanskrit Sansthan, fifth edition, 2001, pn. 425,426 .

21 . Acharya J.T. and Acharya N.R. Sushruta Samhita of Sushruta with nibandhasangraha commentary of Sri Dalhanacharya, Varanasi, Chaukhambha orientalia, fifth edition 1992, pn.688, 690

22 Acharya J.T. Charaka samhita by Agnivesha revised by charaka and Dridhabala with the Ayurved Dipika commentary of Chakrapanidatta, Varanasi, Chaukhambha Sanskrit Sansthan, fifth edition, 2001, pn.405,426.

23 . Acharya J.T. and Acharya N.R. Sushruta Samhita of Sushruta with nibandhasangraha commentary of Sri Dalhanacharya, Varanasi, Chaukhambha orientalia, fifth edition 1992, pn.678

24 Acharya J.T. Charaka samhita by Agnivesha revised by charaka and Dridhabala with the Ayurved Dipika commentary of Chakrapanidatta, Varanasi, Chaukhambha Sanskrit Sansthan, fifth edition, 2001, pn. 424,425 .

25 . Acharya J.T. and Acharya N.R. Sushrutasamhita of Sushruta with nibandhasangraha commentary of sri Dalhanacharya, Varanasi, Chaukhambha orientalia, fifth edition 1992, pn.201,407

26 Acharya J.T. Charaka samhita by Agnivesha revised by charaka and Dridhabala with the Ayurved Dipika commentary of Chakrapanidatta, Varanasi, Chau- khambha Sanskrit Sansthan, fifth edition, 2001, pn.405, 426 .

27 Acharya J.T. and Acharya N.R. Sushruta Samhita of Sushruta with nibandhasangraha commentary of Sri Dalhanacharya, Varanasi, Chaukhambha orientalia, fifth edition 1992, pn.677,691

28 Acharya J.T. Charaka samhita by Agnivesha revised by charaka and Dridhabala with the Ayurved Dipika commentary of Chakrapanidatta, Varanasi, Chaukhambha Sanskrit Sansthan, fifth edition, 2001, pn.203.

29 . Acharya J.T. and Acharya N.R. Sushruta Samhita of Sushruta with nibandhasangraha commentary of Sri Dalhanacharya, Varanasi, Chaukhambha orientalia, fifth edition 1992, pn.689

30 Acharya J.T. Charaka samhita by Agnivesha revised by charaka and Dridhabala with the Ayurved Dipika commentary of Chakrapanidatta, Varanasi, Chaukhambha Sanskrit Sansthan, fifth edition, 2001, pn.427.

31 . Acharya J.T. and Acharya N.R. Sushruta Samhita of Sushruta with nibandhasangraha commentary of Sri Dalhanacharya, Varanasi, Chaukhambha orientalia, fifth edition 1992, pn.678

32 Acharya J.T. and Acharya N.R. Sushruta Samhita of Sushruta with nibandhasangraha commentary of Sri Dalhanacharya, Varanasi, Chaukhambha orientalia, fifth edition 1992, pn.695

\section{Source of Support: Nil Conflict of Interest: None Declared}

How to cite this URL: Avula Srinivas: Comparative Analysis Of Jwara Chikitsa Siddhanta Among The Charaka Samhita And Sushruta Samhita. International Ayurvedic Medical Journal \{online\} 2021 \{cited October 2021\} Available from: http://www.iamj.in/posts/images/upload/2472_2480.pdf 